\title{
First report of Lasiodiplodia pseudotheobromae causing twig and stem blight of Gossypium hirsutum in Pakistan
}

\author{
Sumera $\mathrm{Naz}^{1} \cdot$ Saira Mehboob ${ }^{1} \cdot$ Muhammad Waqar Alam $^{2} \mathbb{D} \cdot$ Abdul Rehman $^{3} \cdot$ Muhammad Idrees $^{1}$
}

Received: 24 January 2021 / Accepted: 15 April 2021 / Published online: 28 April 2021

(c) Società Italiana di Patologia Vegetale (S.I.Pa.V.) 2021

Keywords Cash crop · Twig blight $\cdot$ Lasiodiplodia pseudotheobromae

Gossypium hirsutum (upland cotton) is an important cash crop and considered as integral part to the economic development of Pakistan (Razzaq et al. 2021). In August-September 2018, severe twig and stem blight was observed in Multan and Bahawalpur districts of Punjab, Pakistan. The disease incidence ranged from 20 to $40 \%$. Symptoms included necrotic twigs with attached leaves and dark-brown stem due to discolored xylem along with abundant, black, and solitary pycnidia. Possible fungal causal agent was isolated from symptomatic samples surface-disinfected with $1 \%$ sodium hypochlorite, rinsed with sterile water, transferred to potato dextrose agar and incubated at $28{ }^{\circ} \mathrm{C}$ for 7 days. The fungus produced thick, fluffy and greyish-white colonies. The colonies turned into dark gray after 5 to 7 days of incubation. Conidia ( 24.5 to $31.5 \times 11.4$ to $15.7 \mu \mathrm{m}$ ) were unicellular, ellipsoidal, initially hyaline, became dark brown with age. There were many conidiophores ( 5 to $14 \times 3$ to $4 \mu \mathrm{m}$ ) on the inner walls. Conidiogenous cells were hyaline, cylindrical and holoblastic. The morphology of the fungus was similar to Lasiodiplodia spp. (Alves et al. 2008). The pathogen identity to species level was verified by amplification of internal transcribed spacer (ITS) region of rDNA and translation elongation factor 1-alpha (TEF1- $\alpha$ ) gene using ITS1/ITS4 and EF1-728F/EF1-986R primer sets, respectively. Sequences were deposited to GenBank (accession Nos. MW487242 for ITS and MW508848 for TEF1- $\alpha$ ). BLAST analysis showed 100\% homology with Lasiodiplodia

Muhammad Waqar Alam

waqar.alam@imbb.uol.edu.pk

1 Plant Pathology Section, Plant Pathology Research Institute, Ayub Agriculture Research Institute, Jhang Road, 38000 Faisalabad, Pakistan

2 Institute of Molecular Biology and Biotechnology, The University of Lahore, Lahore, Pakistan

3 Department of Plant Pathology, University of Agriculture, 38040 Faisalabad, Pakistan pseudotheobromae A.J.L. Phillips, A. Alves \& Crous. To assess pathogenicity, 10 five- to seven-week-old plants were inoculated using flap method with 60 to $70 \%$ relative humidity. Control plants were inoculated with PDA only. Eight to twelve days post inoculation, symptoms identical to those observed in cotton fields were visible except controls. The pathogen was successfully re-isolated from inoculated plants. There is no available data on $L$. pseudotheobromae associated with cotton crop. To our knowledge, this is the first report of this emerging threat on cotton crop in Punjab, Pakistan, and worldwide (Farr and Rossmann 2021).

\section{References}

Alves A, Crous PW, Correia A, Phillips AJL (2008) Morphological and molecular data reveal cryptic speciation in Lasiodiplodia theobromae. Fungal Div 28:1-13

Farr DF, Rossman AY (2021) Fungal Databases, U.S. National Fungus Collections, ARS, USDA

Razzaq A, Zafar MM, Ali A, Hafeez A, Batool W, Shi Y, Gong W, Yuan Y (2021) Cotton germplasm improvement and progress in Pakistan. J Cotton Res. https://doi.org/10.1186/s42397-020-00077-x

Publisher's Note Springer Nature remains neutral with regard to jurisdictional claims in published maps and institutional affiliations. 